\title{
Collection and measurement of aerosols of viable influenza virus in liquid media in an Andersen cascade impactor
}

This article was published in the following Dove Press journal:

Virus Adaptation and Treatment

17 December 2014

Number of times this article has been viewed

\author{
Kevin P Fennelly ${ }^{1-3}$ \\ Matthew D Tribby ${ }^{2,4}$ \\ Chang-Yu Wu ${ }^{2,4}$ \\ Gary L Heil ${ }^{5}$ \\ Lewis J Radonovich ${ }^{3}$ \\ Julia C Loeb ${ }^{2,6}$ \\ John A Lednicky ${ }^{2,6}$
}

'Department of Medicine, ${ }^{2}$ Emerging Pathogens Institute, ${ }^{3}$ Veterans Health Administration's National Center for Occupational Health and Infection

Control, ${ }^{4}$ Environmental Engineering Sciences, ${ }^{5}$ Environmental Health and Safety, ${ }^{6}$ Environmental and Global Health, University of Florida, Gainesville, FL, USA
Correspondence: John A Lednicky Department of Environmental and Global Health, University of Florida, I225, Gainesville, FL, 32610-0188, USA

Tel +l 3522739204

Fax +I 3522736070

Email jlednicky@phhp.ufl.edu
Abstract: The modes of person-to-person transmission of influenza viruses, particularly the contribution of airborne transmission via inhalation of fine ( $<5$ microns) particles are highly debated. Furthermore, airborne influenza virus particles collected from patients in recent studies used methods that, unfortunately, cannot discriminate between viable (infectious) or nonviable virus. We aimed to assemble an aerosol-generating and -measuring system to safely generate sizecharacterized aerosols of viable influenza virus, and evaluated the method of use of a six-stage Andersen cascade impactor for the collection of influenza virus aerosols. The long-term goal was to develop a facile sampling method for use in future field studies of viable airborne influenza virus in clinical settings. Experimental results showed that the aerosol-generating system safely and consistently produced fine aerosols with a count median aerodynamic diameter (CMAD) of $0.87 \mu \mathrm{m}$. Sampling of aerosolized viable virus was first attempted by direct impaction of the aerosol onto monolayers of indicator cells. We found that cultures of MDCK and Mv1-Lu cells initially kept under a minimal layer of cell growth medium in plastic Petri dishes could survive short-term desiccation resulting from a flowing airstream, in an Andersen single-stage impactor ( $100 \%$ up to 4 minutes). Unfortunately, the cells' sensitivity to the stresses of transport indicated that direct collection onto live cell monolayers was impractical outside of a laboratory setting. In contrast, recovery of viable virus was effective and facile if the aerosol was collected in liquid media in Petri dishes in an Andersen cascade impactor and then inoculated onto cell cultures. Collection efficiencies in all investigated air samplers ranged from 3\%-6\%, which highlights the need for more effective air samplers for airborne virus collection.

Keywords: air sampling, aerosol generation

\section{Introduction}

Pandemic influenza remains a global public health threat. Although there is evidence that influenza viruses can be transmitted by airborne routes, ${ }^{1-4}$ the importance of the modes of person-to-person transmission of influenza viruses remain poorly understood. This scientific uncertainty has impeded the development and acceptance of consistent influenza infection control strategies. ${ }^{5}$ Methods that can safely and efficiently generate, sample, and measure particle sizes in aerosols containing both viable ("infectious") and nonviable ("noninfectious") influenza virus are thus critically important to developing better influenza infection control strategies.

Breathing, coughing, sneezing, and talking by persons with influenza generate a cloud of airborne particles that contain influenza virus. The expired airborne particles range in size from a few millimeters (large droplets formed during coughing and sneezing) to submicron $(<1 \mu \mathrm{m})$ (formed during breathing). Small particles $(\leq 5 \mu \mathrm{m})$, 
including droplet nuclei that result from evaporated larger particles, can remain airborne for hours. ${ }^{1,3-16}$ Fecal-oral or waterborne transmission of influenza viruses occur among birds, ${ }^{17,18}$ which are important natural hosts of influenza viruses, but not in humans, in whom influenza viruses are thought to be primarily transmitted through four routes of infection:

1. Droplet infection, which occurs when droplets deposit on mucous surfaces of the upper respiratory tract (URT), such as the mouth and nose. Droplets can be inhaled, but those that are $>10 \mu \mathrm{m}$ remain in the URT and do not reach the lungs

2. Inhalation of small aerosols and droplet nuclei. These small airborne particles $(\leq 5 \mu \mathrm{m})$ reach the lower respiratory tract (LRT) and can also be deposited on surfaces of the URT. Importantly, deposition of influenza virus into the lungs (as small particles) versus the URT (as large droplets) may increase infection risk and illness severity ${ }^{3,10,19-21}$

3. Contact transmission, which occurs when virus-containing fomites are indirectly transferred to mucous membranes of the URT, or through direct contact with infected individuals

4. Ocular infection (currently shown only in animal models) occurs when airborne influenza viruses (presumably either droplets or aerosols) come into contact with ocular surfaces, which serve both as a site of virus entry and replication. $^{22}$

Airborne viruses are typically detected and identified by a multistep process. First, "active sampling" is used, wherein a microbiological air sampler mechanically draws a known volume of air over, or through, a particle collection device. ${ }^{23}$ The collected virus particles are subsequently removed from the collection medium and analyzed. However, it is technically difficult to effectively collect airborne viruses using commonly available air samplers, for reasons that include: 1) viruses occur at relatively low concentration in ambient air, 2) the air samplers typically run for short periods of time (minutes), making it difficult to capture large volumes, 3 ) most do not separate particles by size, and 4) the air samplers are inefficient at collecting submicron particles ${ }^{24-27}$ because they were originally designed for collecting bacteria and fungi that are larger in size. An added complication is that viruses are often damaged/inactivated during collection using air samplers, due to the stresses and forces acting upon them. ${ }^{24,28-31}$

To be able to evaluate and compare different methods for detecting viable viral aerosols, our first goal was to develop a system that could safely, efficiently, and consistently generate aerosolized influenza virus. The viral aerosol-generation system was coupled with a bioaerosol sampler for characterizing airborne particles associated with viable influenza viruses. We then devised and validated a new sampling approach of direct impaction of the aerosol onto monolayers of indicator cells. The ultimate goal is to adopt the validated system and approach, to better understand the transmission modes of influenza viruses.

\section{Materials and methods Design of the viral aerosol-generation and -measurement system (AGAMS)}

Figure 1 is a schematic illustration of the viral AGAMS. Two compressed air tanks fed dry air into the system, with their flow rates controlled by two rotameters (Omega Engineering Inc., Stamford, CT, USA). Each rotameter in the system was calibrated with a Bios MesaLabs Drycal Defender 530 (Brandt Instruments, Inc., Prairieville, LA, USA). A six-jet Collison pneumatic nebulizer (CN25; BGI Inc., Waltham, MA, USA) was used to generate aerosols within the inhalable range (particle diameter $\leq 5 \mu \mathrm{m}$ ). ${ }^{32,33}$ A sample reservoir containing virus in liquid suspension was affixed to the bottom of the nebulizer unit. High-pressure air fed into the nebulizer exited out of the six ports located toward the bottom of the nebulizer, as high-velocity air jets that entrained the liquid to form droplets. Large droplets impacted the side of the container and were recycled into the original liquid medium, while smaller droplets sustained their airborne state and were carried out of the nebulizer. The unit was operated with pressurized air at $40 \mathrm{psi}$, which equates to roughly $20 \mathrm{~L} / \mathrm{min}$ of free air use. ${ }^{34}$

As enveloped viruses can get damaged in the Collison Nebulizer, we also considered an alternative device for generating fine aerosols. The sparging liquid aerosol generator (SLAG) (CH Technologies, Westwood, NJ, USA) creates aerosols through a bursting bubble method, which reduces the shear forces on particles being aerosolized. ${ }^{35}$ It has not been used for many virology studies to date but has been advantageous for inhalation-exposure studies of aerosolized bacteria ${ }^{36}$ (KP Fennelly, unpublished data; 2008-2010). Liquid medium containing viable virus was fed by a Masterflex ${ }^{\circledR} \mathrm{C} / \mathrm{L}$ dual-channel (10-60 rpm, $12 \mathrm{~V}$ DC) peristaltic pump and delivered to a 1-inch porous disk via a needle. As the medium dripped onto the porous disk to form a thin liquid film, high-pressure air directed through the porous disk broke apart the thin liquid film into bubbles containing particles. Bubbles have the tendency to burst, due 


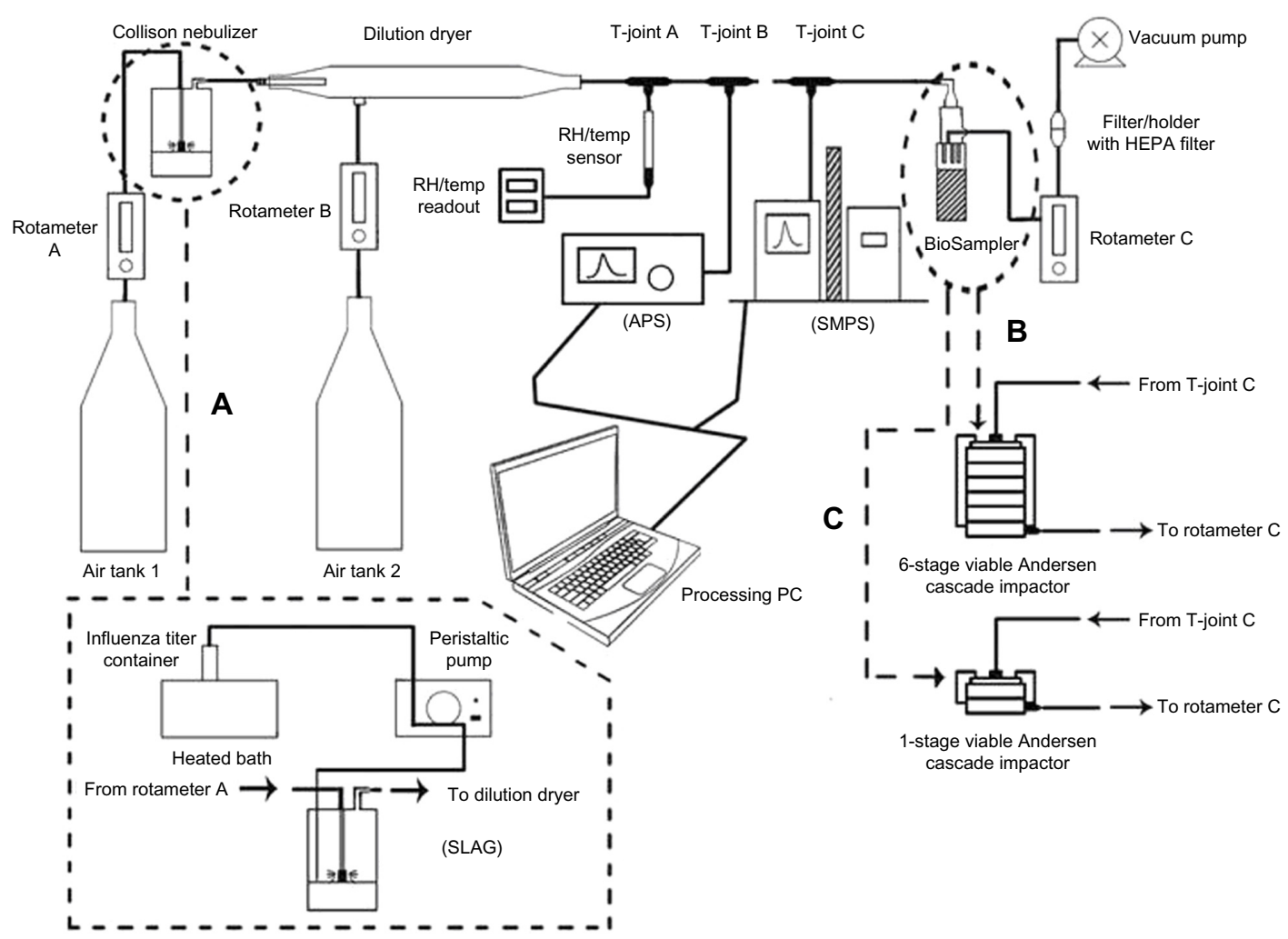

Figure I Schematic illustration of the viral AGAMS.

Notes: Key components are identified. Aerosols are generated at the Collison nebulizer (upper left) and are exhausted through a terminal HEPA filter (upper right). The BioSampler (SKC Inc., Eighty Four, PA, USA) and the six-stage viable Andersen cascade impactor (Thermo Fisher Scientific, Inc., Waltham, MA, USA) are attached to the AGAMS at T-joint $C$.

Abbreviations: AGAMS, aerosol-generation and -measurement system; APS ${ }^{\mathrm{TM}}$, Aerodynamic Particle Sizer ${ }^{\circledR}$ (spectrometer); HEPA, high-efficiency particulate air; SLAG, Sparging liquid aerosol generator; SMPS TM, Scanning Mobility Particle Sizer (spectrometer).

to an expanding pressure gradient between the inside and outside of the bubble. ${ }^{35}$ In this study, air flow through the SLAG was delivered at 10 liters per minute. Noteworthy, not all of the liquid medium introduced into the SLAG is successfully aerosolized. Residual liquid tends to build up at the inner bottom of the SLAG.

The produced fine aerosols then entered the dilution dryer, which can be operated with or without drying air. In the latter mode, the humidity of the aerosol stream can be regulated and the liquid droplets evaporated to droplet nuclei. ${ }^{23,37}$ The relative humidity and temperature were monitored by a relative humidity and temperature transmitter (model HX93DACRP1-F; Omega Engineering, Inc.). Airstreams from the nebulizer and the dry air line combined in the dilution dryer and flowed to the collection device. Two slit-streams of the aerosol flow were directed to on-line instruments for realtime aerosol size distribution measurements and for verifying consistency: an Aerodynamic Particle Sizer ${ }^{\circledR}$ spectrometer (APSTM model 3321; TSI Inc., Shoreview, MN, USA) and a Scanning Mobility Particle Sizer spectrometer (SMPS ${ }^{\text {TM }}$ model 3936, TSI, Inc.). The APS was used to obtain the aerodynamic size distribution of aerosols from 0.5 to $20 \mu \mathrm{m}$ in diameter up to 1,000 particles $/ \mathrm{cm}^{3}$, based on the time-offlight principle. ${ }^{38-40}$ The SMPS was used to measure aerosol size distribution of aerosols between $0.003-1 \mu \mathrm{m}$ and concentration range of $20-10^{7}$ particles $/ \mathrm{cm}^{3}$, based on the particle's electrical mobility. ${ }^{41}$

The aerosols were then collected downstream, either with a Six-Stage Andersen Cascade Impactor (ACI) (catalog number 10830-EPD; Thermo Fisher Scientific, Inc., Waltham, MA, USA) or a BioSampler (BSR) (catalog number 225-9595; SKC Inc., Eighty Four, PA, USA): the ACI was used for measuring the size distribution of airborne particles that associated with viable influenza viruses and the quantification of the collected microorganisms, whereas the BSR was used to collect and verify the presence of viable airborne influenza viruses. The BSR is a more recent version of an impinger-type air sampler, ${ }^{42}$ which collects airborne particles using a swirling flow of liquid media, created by passing air through three $0.630 \mathrm{~mm}$ tangential sonic nozzles. Compared with older impinger designs, particle skip and damage to the collected microbial agent are potentially minimized by 
the collection swirling liquid. ${ }^{43}$ The BSR has worked well for the collection of airborne bacteria and fungi in the field. However, it is inefficient at recovering submicrometer and ultrafine virus aerosols, with collection efficiencies of $<10 \%$ for particles in the 30 to $100 \mathrm{~nm}$ size range when used following the manufacturer's recommendations. ${ }^{44,45}$ Nevertheless, mostly because significantly better alternative devices are not readily available, the BSR has been used for the collection of airborne influenza virus. ${ }^{8,16,24,46,47}$ Based on our pilot studies, the BSR was operated at a sampling rate of $8 \mathrm{LPM}$ instead of the manufacturer's recommended sampling rate of 12.5 LPM (for the collection of airborne bacteria and fungi), and operated using a 115 V Vac-U-Go Sample Pump (catalog number 228-9605; SKC Inc.). The collection medium consisted of $15 \mathrm{~mL}$ of sterile phosphate-buffered saline (PBS) containing $0.5 \%(\mathrm{w} / \mathrm{v})$ purified bovine serum albumin (BSA) fraction V (Life Technologies Corp, Carlsbad, CA, USA) and 0.25\% (v/v) molecular-grade antifoam B (Sigma-Aldrich Corp, St Louis, MO, USA)..$^{10,16}$

The ACI consists of a flow tube with six intervening stages through which an airstream is pulled and wherein the aerosolized particles are collected through physical impaction onto a collection medium at the different stages. Each stage consists of a plate with 400 perforated holes and immediately below, a Petri dish of collection medium. ${ }^{48}$ The diameter of the perforated holes gets smaller with each stage, with the largest holes being found, in stage 1 , with a $1.18 \mathrm{~mm}$ diameter and the smallest, in stage 6 , with a $0.25 \mathrm{~mm}$ diameter. ${ }^{49}$ The jet velocity through each perforated hole is uniform at each stage but increases as the flow moves down the device, due to the decreasing diameters of the perforated holes. The ACI is designed for use with an input flow of $28.3 \mathrm{~L} / \mathrm{min} .^{48,49}$ The stages have a sharp cutoff diameter (median cut point [D50]) as follows: $>7 \mu \mathrm{m}$ (stage 1); 4.7-7 $\mu \mathrm{m}$ (stage 2); 3.3-4.7 $\mu \mathrm{m}$ (stage 3 ); 2.1-3.3 $\mu \mathrm{m}$ (stage 4); 1.1-2.1 $\mu \mathrm{m}$ (stage 5); and 0.65-1.1 $\mu \mathrm{m}$ (stage 6). Though more cumbersome to use, a major advantage of the ACI over the BSR is that a particle size distribution is determined, and the latter information is important for assessments of the inhalation risk of small airborne particles that may be deposited in the lower lungs.

In addition, a Biostage ${ }^{\circledR}$ Single-stage Viable Cascade Impactor (catalog number 225-9611; SKC Inc.) was also used. This impactor has a D50 of $0.6 \mu \mathrm{m}$, which is similar to stage 6 of the ACI. As for the ACI, it was operated at an input flow of $28.3 \mathrm{~L} / \mathrm{min}$.

After the sampler, the air stream exited through a third rotameter (Omega Engineering Inc.) into a high-efficiency particulate air (HEPA) filter before being exhausted.
The terminal rotameter measured airflows exiting the collection device and aided in assessing whether adequate airflows were generated for proper function of the collection devices. An oilless sampling pump was attached to the end of the system. The inlet to the sampling pump was also equipped with a vapor trap to minimize liquid buildup in the pump.

The main body of the AGAMS was housed within a NuAire Class II type a2 biological safety cabinet, whereas the APS and SMPS were located outside the biological safety cabinet, with the entire assembly within a biosafety level 2-enhanced laboratory.

\section{Cell lines}

MDCK (CCL-34) and Mv1 Lu (CCL-64) cells were obtained from the ATCC (Manassas, VA, USA) and propagated as monolayers at $37^{\circ} \mathrm{C}$ and $5 \% \mathrm{CO}_{2}$ in Eagle's minimal essential medium (EMEM) (Life Technologies Corp). The EMEM contained 2 mM L-alanyl-L-glutamine (GlutaMAX ${ }^{\text {TM}}$; Life Technologies Corp), antibiotics $(50 \mu \mathrm{g} / \mathrm{mL}$ penicillin, $50 \mu \mathrm{g} /$ $\mathrm{mL}$ streptomycin, $100 \mu \mathrm{g} / \mathrm{mL}$ neomycin) (PSN) (Invitrogen; Life Technologies Corp), 10\% (v/v) low immunoglobulin (Ig)G, heat-inactivated gamma-irradiated fetal bovine serum (FBS) (HyClone Laboratories Inc., Logan, UT, USA), 1 mM sodium pyruvate (Invitrogen; Life Technologies Corp), and $1 \times$ Non-Essential Amino Acids (HyClone Laboratories Inc.). Prior to use, the cell lines were treated for 3 weeks with Plas$\operatorname{mocin}^{\mathrm{TM}}$ and were verified to be free of mycoplasma DNA by polymerase chain reaction (PCR)..$^{50}$

\section{Virus strains and virus propagation}

Since pandemic $2009 \mathrm{H} 1 \mathrm{~N} 1$ viruses continue to circulate, modeling was performed with wild-type influenza virus strain A/Mexico/4108/2009 (H1N1), which was obtained from the Centers for Disease Control and Prevention (CDC). Viruses A/Puerto Rico/8/1934 (H1N1) A/New Caledonia/20/1999 (H1N1), A/California/04/2009 (H1N1), A/California/07/2009 (H1N1) A/Hong Kong/8/1968 (H3N2), and A/Wisconsin/67/2005 (H3N2) were from the collection of John Lednicky. Various influenza virus strains were used in cell-validation assays to ensure that sensitive indicator cells were chosen for virus isolation and viral enumeration assays/measures of viral viability. The viruses were propagated in MDCK cells in serum-free cell growth media with $2 \mu \mathrm{g} / \mathrm{mL}$ of tosyl phenylalanyl chloromethyl ketone (TPCK)-trypsin, and the median tissue culture infectious dose $\left(\right.$ TCID $\left._{50}\right)$ determined in MDCK cells, as previously described. ${ }^{51}$ Each virus had been propagated under conditions wherein relatively few defective particles were 
formed, resulting in a virus stock with an infectious virus particle-to-virus genome equivalent of about 1:100. Briefly, starting with a titered stock of influenza virus, confluent cells in a minimal volume of serum-free cell culture medium with TPCK-trypsin were infected with virus at a multiplicity of infection (MOI) of $0.01-0.001$ and incubated at $33^{\circ} \mathrm{C}$ to $34^{\circ} \mathrm{C}$ for 2 hours. Additional cell growth medium containing TPCK-trypsin was added, and the cells were incubated until $80 \%$ of the cells were swollen and detached from the growing surface of the cell culture flask. During the virus propagation procedure, the cell culture medium was collected daily starting on day 2 postinfection, adjusted to $0.5 \%$ (weight to volume) purified BSA fraction $\mathrm{V}$, clarified by centrifugation at low speed, and the supernatant stored at $-80^{\circ} \mathrm{C}$. Virus yields typically peak 2 to 3 days postinfection, before the formation of extensive influenza virus-specific cytopathic effects. The collected frozen material was subsequently thawed once, pooled, aliquoted, and refrozen at $-80^{\circ} \mathrm{C}$ for short-term storage (up to 3 months) or stored in the vapor phase of a liquid nitrogen cryotank for long-term storage. Influenza virus was aerosolized in a solution consisting PBS $+0.5 \% \mathrm{w} / \mathrm{v}$ BSA fraction $\mathrm{V} .{ }^{10} \mathrm{~A}$ total of $20 \mathrm{~mL}$ of virus suspension was used for each trial.

\section{Quantitative reverse-transcription PCR (qRT-PCR)}

For analysis by qRT-PCR, viral RNA was extracted from $140 \mu \mathrm{L}$ of sample material and collected in $80 \mu \mathrm{L}$ of elution buffer, using a QIAamp Viral RNA Mini Kit (Qiagen, Valencia, CA, USA). Quantification of viral genome copy number was performed in triplicate using a Bio-Rad QX100 ${ }^{\mathrm{TM}}$ Droplet DigitalTM PCR System, using One-Step RT-ddPCR Kit for Probes (catalog number 186-3021) and the CDC influenza A-specific primer and probe set.

\section{Experimental conditions}

Whereas MDCK cells are considered the standard cell line for the propagation of human influenza viruses, they consist of a heterogeneous cell population, and MDCK cells from different sources vary in the modal number of chromosomes, morphology, "tightness" of cell-to-cell junctions, and other characteristics. ${ }^{51-53}$ Thus, their suitability for influenza virus work varies from batch to batch. Similarly, Mv1 Lu cells from different sources vary in their utility as sensitive indicator cells for the isolation and propagation of human influenza viruses. ${ }^{51}$ Following standard practices, ${ }^{50,51}$ cryopreserved MDCK and Mv1 Lu cells that had been previously validated for human influenza virus work were function-tested in triplicate against various human influenza subtype $\mathrm{H} 1$ and H3 viruses.

To overcome the low efficiency of conventional air samplers for collecting viral aerosols, we sought to determine whether viable airborne influenza viruses might be efficiently detected if they were impacted a) directly onto a monolayer of cells on the growing surface of a Petri dish or b) into a cell culture medium over a monolayer of cells, during air sampling with Andersen-type cascade impactors. Sterile polystyrene Petri dishes used for the preparation of bacterial growth plates (MidSci, St Louis, MO, USA) and Corning ${ }^{\circledR}$ tissue-culture treated culture dishes (Sigma-Aldrich Corp) were evaluated as growth vessels for the cell monolayers. Treble ( $n=3$, independent) runs were performed for timed intervals ranging from $0.5,1,2,3,4,5$, to 10 minutes, at a collection flow rate of $28.3 \mathrm{~L} / \mathrm{min}$. Subsequent to air sampling, the cells were trypsinized and viability was judged using a standard trypan blue viability (exclusion) test, and by replating the cells onto new Petri dishes for confirmation of cell viability.

The impaction surface of Petri dishes in Andersentype cascade impactors should be positioned an optimal distance from the cascading airstream. For the unit tested, $28 \mathrm{~mL}$ of sterile melted agar growth media would normally be added to glass Petri dishes supplied by the manufacturer, resulting in formation of a semisolid impaction surface at the correct distance from the cascading airstream upon solidification of the agar medium. The polystyrene Petri dishes used for this project required an addition of only $20 \mathrm{~mL}$ of liquid medium to produce an impaction surface at an optimal distance from the airstream. Treble ( $\mathrm{n}=3$, independent) runs were performed for timed intervals ranging from $0.5,1,2,3,4,5$ to 10 minutes at a collection flow rate of $28.3 \mathrm{~L} / \mathrm{min}$. Subsequent to air sampling, the cells were trypsinized and viability judged as described above.

To ensure the cells could endure stress during air sampling in the new method, they were tested before experiments with influenza viruses, cell culture medium was removed from confluent cell monolayers grown in Petri dishes, and the cells were immediately tested in triplicate during timed air samplings. At the start of the air sampling process, the cells were covered with $250 \mu \mathrm{L}$ of cell growth medium (just enough to keep the cells wet).

All work was performed in a biosafety level 2-enhanced laboratory. Workers were vaccinated against influenza $A$ and $B$ viruses, and worked under laboratory coats, gloves, and N95 masks and eye protectors. 


\section{Results}

\section{Validation of MDCK and MvI Lu cells and their survival during air-sampling}

As shown in Table 1, after infection with virus at a MOI of 0.01 , virus yields were at the expected range $\left(10^{7}\right.$ or higher) when the cell lysates were collected after $80 \%$ of the infected cells had detached from the growing surface. Furthermore, virus yields were higher in Mv1 Lu cells than in MDCK cells, as previously observed for other contemporary human influenza viruses. ${ }^{51}$

Following validation of MDCK and Mv1 Lu for influenza virus, we verified survival of these cells during air sampling in a Biostage single-stage viable impactor. The results showed that cell culture-treated Petri dishes were not necessary; both standard bacterial Petri dishes and treated cell culture dishes worked equally well. Most monolayer cells tolerated shortterm desiccation during air sampling in the Biostage singlestage viable impactor and survived for up to 10 minutes of air sampling (Table 2). Prior to these tests, pilot studies indicated that barely wet MDCK and Mv1 Lu cells survived for $>8$ hours at $37^{\circ} \mathrm{C}$ in a humid incubator provided they were covered (and not under a moving airstream that would fully desiccate the cells). ${ }^{16}$ Similarly, confluent cells submerged under cell growth medium survived up to 10 minutes of air sampling when they were used within 5 minutes after removal from the incubator (Table 3).

\section{Generation of fine aerosols using a Collison nebulizer in the AGAMS}

Function and safety tests were used to establish operating parameters for the Collison nebulizer as the aerosol generation device in the AGAMS, using influenza virus in a PBSBSA aerosol vehicle. After extensive tests, it was determined that incoming air should be fed at 35 psi (controlled using a regulator) into the nebulizer intake line, and at 20 psi into the dry air line. The pressure was greater into the nebulizer

Table I Titers $\left(\log _{10} \mathrm{TCID}_{50} / \mathrm{mL}\right)$ of seasonal and pandemic 2009 influenza A viruses in MDCK and MvI Lu cells

\begin{tabular}{lll}
\hline Virus & MDCK cells & MvI Lu cells \\
\hline A/Puerto Rico/8/1934 (HINI) & $7.1 \pm 0.3$ & $8.2 \pm 0.2$ \\
A/New Caledonia/20/I999 (HINI) & $7.9 \pm 0.3$ & $8.6 \pm 0.2$ \\
A/California/04/2009 (HINI) & $7.1 \pm 0.1$ & $7.9 \pm 0.3$ \\
A/California/07/2009 (HINI) & $7.2 \pm 0.1$ & $7.8 \pm 0.2$ \\
A/Mexico/4I08/2009 (HINI) & $6.9 \pm 0.2$ & $8.1 \pm 0.3$ \\
A/Hong Kong/8/I968 (H3N2) & $8.1 \pm 0.4$ & $8.8 \pm 0.2$ \\
A/Wisconsin/67/2005 (H3N2) & $7.9 \pm 0.1$ & $8.9 \pm 0.2$ \\
\hline
\end{tabular}

Abbreviation: $\mathrm{TCID}_{50} / \mathrm{mL}$, median tissue culture infectious dose.
Table 2 Survival (\%) of exposed cell monolayers during shortterm air sampling

\begin{tabular}{lll}
\hline $\begin{array}{l}\text { Air-sampling } \\
\text { time }\end{array}$ & $\begin{array}{l}\text { \% survival in } \\
\text { MDCK cells }\end{array}$ & $\begin{array}{l}\text { \% survival in } \\
\text { Mv I Lu cells }\end{array}$ \\
\hline 30 seconds & 100 & 100 \\
I minute & 100 & 100 \\
2 minutes & 100 & 100 \\
3 minutes & 100 & 100 \\
4 minutes & 100 & 100 \\
5 minutes & $97 \pm I$ & $98 \pm I$ \\
10 minutes & $92 \pm 2$ & $93 \pm 3$ \\
\hline
\end{tabular}

due to the higher resistance of the device. It was also determined that the total air flow leaving the dilution dryer tube was $29.8 \mathrm{~L} / \mathrm{min}$. After an air flow of $5 \mathrm{~L} / \mathrm{min}$ diverted to the APS, the total air flow reaching the sampler was $28.3 \mathrm{~L} / \mathrm{min}$. Liquid consumption from the nebulizer reservoir averaged $0.32 \mathrm{~mL} / \mathrm{min}$. Following these parameters, aerosols (measured using the APS) were produced, with a count median aerodynamic diameter (CMAD) of $0.87 \pm 0.07 \mu \mathrm{m}$ $(\mathrm{N}=3)$ and a geometric standard deviation of $1.62 \pm 0.15$. These results proved that the AGAMS with a Collison nebulizer produced fine aerosols, of the desired size range (particle diameter $<5 \mu \mathrm{m}$ ) and for modeling work.

\section{Stability of influenza virus in a Collison nebulizer and starting concentration for aerosol studies}

Having determined that the Collison-AGAMS was safe to use (free of leaks), the dynamics of producing and collecting influenza virus aerosols using a Collison nebulizer were analyzed, in triplicate, under temperatures of $70.2^{\circ} \mathrm{F}$ to $70.5^{\circ} \mathrm{F}$ $\left(21.2^{\circ} \mathrm{C}\right.$ to $\left.21.39^{\circ} \mathrm{C}\right)$ and relative humidities ranging from about $35.5 \%$ to $46 \%$. The results showed that after a 10 -minute run, $50 \%-70 \%$ of the virus in the nebulizer reservoir had been inactivated. This was determined by calculating the infectivity/genome equivalency ratios of the virus in the Collison reservoir at the start and end of each run, compared

Table 3 Survival (\%) of submerged cell monolayers during shortterm air sampling

\begin{tabular}{lll}
\hline $\begin{array}{l}\text { Air-sampling } \\
\text { time }\end{array}$ & $\begin{array}{l}\text { \% survival in } \\
\text { MDCK cells }\end{array}$ & $\begin{array}{l}\text { \% survival in } \\
\text { Mv I Lu cells }\end{array}$ \\
\hline 30 seconds & 100 & 100 \\
I minute & 100 & 100 \\
2 minutes & 100 & 100 \\
3 minutes & 100 & 100 \\
4 minutes & 100 & 100 \\
5 minutes & 100 & 100 \\
10 minutes & 100 & 100 \\
\hline
\end{tabular}


with mock nebulized virus otherwise maintained under the same conditions. Considering both the survivability of the virus and the limits of detection by TCID $_{50}$ assay, a starting concentration of at least $1 \times 10^{6} \mathrm{TCID}_{50} / \mathrm{mL}$ would be needed in the nebulizer reservoir.

\section{Collection of aerosolized influenza virus particles in a BSR}

After confirming that influenza viruses could be safely aerosolized using a Collison nebulizer in the AGAMS, we next assessed the suitability of a BSR for virus collection. Under the temperature conditions and nebulizing times used for this work, influenza virus A/Mexico/4108/2009 (H1N1) remained fully viable in PBS-BSA. Using the BSR, viable virus was collected at estimated efficiencies ranging from $2.7 \%$ to $4.2 \%$ (based on theoretical recovery of $100 \%$ of the aerosolized viable virus particles). As an example, in one run, $2.2 \times 10^{6} \mathrm{TCID}_{50}$ infectious virus particles were aerosolized in 10 minutes. A total of $6 \times 10^{4} \mathrm{TCID}_{50}$ units of infectious virus were collected in $15 \mathrm{~mL}$ of collection media (corrected for slight loss of volume due to evaporation) at a sampling rate of $8 \mathrm{~L} / \mathrm{min}$. If no virus was inactivated during nebulization, $\left(6 \times 10^{4}\right.$ $\mathrm{TCID}_{50}$ units $/ 2.2 \times 10^{6} \mathrm{TCID}_{50}$ units $) \times 100=2.7 \%$ recovery of infectious virus particles was obtained. This estimate of collection efficiency should be evaluated carefully and represents a low estimate since virus is inactivated during the nebulization process. For example, the collection efficiency appears higher if one estimates $70 \%$ inactivation of the virus during a 10 -minute sampling period: $2.2 \times 10^{6} \times 0.7=6.6 \times 10^{5}$; therefore, $6 \times 10^{4} / 6.6 \times 10^{5}$. At a higher sampling rate $(12.5 \mathrm{~L} / \mathrm{min})$, less viable virus was collected (collection efficiency $<0.2 \%[$ low estimate]). These results inform that a significant proportion of the virus particles are inactivated in the Collison nebulizer as the virus particles are aerosolized. Moreover, a certain percentage of the virus likely gets damaged during the collection process. Regardless, a significant proportion of the aerosolized virus particles remain viable and are captured in the collection fluid of the BSR at a sampling rate of $8 \mathrm{~L} / \mathrm{min}$. Droplet digital PCR tests confirmed the cell culture tests; calculations of the viral genomic equivalents during the aerosol-generation and -collection phases verified collection efficiencies that ranged from $2.5 \%-4.5 \%$.

\section{Use of MDCK and Mvl Lu cells in conjunction with the $\mathrm{ACl}$}

A long-term goal of our project is to collect and measure the size distribution of aerosolized influenza virus particles, especially in patient settings. For sizing the aerosols, the
ACI would be used with indicator MDCK or Mv1 Lu cells. However, during the course of our investigations, we learned it was impractical to transport cells grown as monolayers in Petri dishes to distant collection sites. Whereas they worked well in a laboratory setting, both barely wet and submerged cell monolayers of MDCK and Mv1 Lu cells often failed. This was attributed to problems associated with spillage from the Petri dishes and a rise of cell growth medium $\mathrm{pH}$, and the resulting stress imposed on the cells.

As an alternative and significantly more practical method, we tested the utility of using Petri dishes filled with PBS-BSA as the collection medium in the ACI. Virus aerosols were generated by the Collison nebulizer and then collected by the ACI, with each collection stage containing a Petri dish filled with $28 \mathrm{~mL}$ of PBS-BSA. Sample results from one run are shown in Table 4. Viable virus was collected at estimated efficiencies ranging from $3 \%-6 \%$, similar to those obtained using a BSR.

\section{Inefficient creation of influenza virus aerosols using a SLAG in the AGAMS}

Whereas the SLAG has been useful for generating bacterial aerosols, viable influenza virus was not collected by the BSR or ACI when it was used to generate aerosols. Specific PCR amplicons were not formed after analyses of the BSR and ACI collection media by influenza virus qRT-PCR.

\section{Discussion}

An aerosol-generation platform (AGAMS) has been developed that has a modular feature to accommodate different types of aerosol-generators and aerosol-samplers. When used in combination with a Collison nebulizer, small particle aerosols of influenza virus can be generated to test the collection efficacy of air-samplers, such as a BSR or the ACI. The use of SLAG as an alternate aerosol-generator for viruses, however, did not produce measurement viruses. To assess large droplets as a transmission mode, it is necessary to

Table 4 Collection of aerosolized influenza virus using an $\mathrm{ACl}$

\begin{tabular}{|c|c|c|}
\hline $\begin{array}{l}\text { ACl stage } \\
\text { number }\end{array}$ & $\begin{array}{l}\text { Cutoff } \\
\text { value }(\mu \mathrm{m})\end{array}$ & $\begin{array}{l}\text { Virus quantity } \\
\text { (TCID }{ }_{50} \text { units) }\end{array}$ \\
\hline I & 7 and above & LOD; $1.04 \times 10^{3}$ \\
\hline 2 & $4.7-7$ & LOD; $1.04 \times 10^{3}$ \\
\hline 3 & $3.3-4.7$ & LOD; $1.04 \times 10^{3}$ \\
\hline 4 & $2.1-3.3$ & LOD; $1.04 \times 10^{3}$ \\
\hline 5 & $1.1-2.1$ & $4.4 \times 10^{4}$ \\
\hline 6 & $0.65-1.1$ & $1.3 \times 10^{5}$ \\
\hline
\end{tabular}

Abbreviations: $\mathrm{ACl}$, Anderson cascade impactor; LOD, level of detection; $\mathrm{TCID}_{50}$, median tissue culture infectious dose. 
produce such larger droplets. Devices, such as a spinning-top aerosol-generator can be incorporated into the AGAMS to produce airborne particles $>5 \mu \mathrm{m}$ in size.

Transport of MDCK or Mv1 Lu cells growing in Petri dishes to distant sites was not practical for use with the ACI. Apart from changes (rise) of $\mathrm{pH}$ of the cell growth medium, leakage and spillage from the Petri dishes was a problem. Additional complications of air-sampling directly onto indicator cells (MDCK or Mv1 Lu) are that contaminating microorganisms (bacteria, fungi) may not be inhibited or killed by antibiotics in the cell culture medium, as well as the need to return the cells to an incubator shortly after air-sampling. A more practical approach is to transport collection medium in sterile containers to the air-sampling site, dispense the medium into Petri dishes at the collection site, and perform air-sampling. The collection media can subsequently be aseptically transferred to sterile collection tubes and maintained on ice for transport to a virology lab, or frozen and stored for future analyses.

Ours is not a report on the collection of airborne influenza virus using an ACI. Previously, influenza virus was collected using semisolid collection media in the Petri dishes of the ACI ${ }^{54-57}$ The collection media of those studies were: $10 \%$ gelatin, ${ }^{54} 2 \%$ agar covered by a thin layer of skim milk, ${ }^{55}$ gelatin filters, ${ }^{56}$ and a filter separated by an agar bottom layer and a gelatin top. ${ }^{57}$ The advantages of using a liquid collection medium over the previously described media are that the preparation of the collection media is simple, and there is no requirement for melting gelatin to recover virus. As the Collison-AGAMS was being tested/ validated with the ACI as a collecting device, we learned that another group has also successfully implemented the use of the ACI for collecting aerosolized influenza virus particles in liquid medium. ${ }^{14}$ Unlike our study, they solely relied on qRT-PCR for the detection of influenza virus RNA, which precluded determination of virus viability. Our studies suggest that the collection of viable airborne influenza virus should also be possible, in clinical or other settings, using liquid collection media in the ACI. A caveat is the collection efficiency is low, highlighting the need for more effective air-samplers for the collection of airborne viruses, as noted before. ${ }^{27}$

\section{Acknowledgments}

This study was supported by a grant from the Veteran's Health Administration. The authors appreciate the assistance of Dr Hsing-Wang Li and Mr Cruz Ortiz of the Department of Environmental Engineering Sciences at the University of Florida. Input from Dr Gregory Gray of Duke University is also gratefully acknowledged.

\section{Disclosure}

The authors report no conflicts of interest in this work.

\section{References}

1. Brankston G, Gitterman L, Hirji Z, Lemieux C, Gardam M. Transmission of influenza A in human beings. Lancet Infect Dis. 2007;7(4):257-265.

2. Hall CB. The spread of influenza and other respiratory viruses: complexities and conjectures. Clin Infect Dis. 2007;45(3):353-359.

3. Tellier R. Aerosol transmission of influenza A virus: a review of new studies. J R Soc Interface. 2009;6 Suppl 6:S783-S790.

4. Belser JA, Maines TR, Tumpey TM, Katz JM. Influenza A virus transmission: contributing factors and clinical implications. Expert Rev Mol Med. 2010;12:e39.

5. Killingley B, Nguyen-Van-Tam J. Routes of influenza transmission. Influenza Other Respir Viruses. 2013;7 Suppl 2:S42-S51.

6. Nicas M, Nazaroff WW, Hubbard A. Toward understanding the risk of secondary airborne infection: emission of respirable pathogens. J Occup Environ Hyg. 2005;2(3):143-154.

7. Weber TP, Stilianakis NI. Inactivation of influenza A viruses in the environment and modes of transmission: a critical review. $J$ Infect. 2008;57(5):361-373.

8. Blachere FM, Lindsley WG, Pearce TA, et al. Measurement of airborne influenza virus in a hospital emergency department. Clin Infect Dis. 2009;48(4):438-440.

9. Stelzer-Braid S, Oliver BG, Blazey AJ, et al. Exhalation of respiratory viruses by breathing, coughing, and talking. J Med Virol. 2009;81(9): 1674-1679.

10. Lednicky JA, Hamilton SB, Tuttle RS, Sosna WA, Daniels DE, Swayne DE. Ferrets develop fatal influenza after inhaling small particle aerosols of highly pathogenic avian influenza virus A/ Vietnam/1203/2004 (H5N1). Virol J. 2010;7:231

11. Fabian P, Brain J, Houseman EA, Gern J, Milton DK. Origin of exhaled breath particles from healthy and human rhinovirus-infected subjects. J Aerosol Med Pulm Drug Deliv. 2011;24(3):137-147.

12. Gralton J, Tovey E, McLaws ML, Rawlinson WD. The role of particle size in aerosolised pathogen transmission: a review. J Infect. 2011;62(1): $1-13$.

13. Lindsley WG, Pearce TA, Hudnall JB, et al. Quantity and size distribution of cough-generated aerosol particles produced by influenza patients during and after illness. J Occup Environ Hyg. 2012;9(7):443-449.

14. Bischoff WE, Swett K, Leng I, Peters TR. Exposure to influenza virus aerosols during routine patient care. J Infect Dis. 2013;207(7): 1037-1046.

15. Milton DK, Fabian MP, Cowling BJ, Grantham ML, McDevitt JJ. Influenza virus aerosols in human exhaled breath: particle size, culturability, and effect of surgical masks. PLoS Pathog. 2013;9(3):e1003205.

16. Lednicky JA, Loeb JC. Detection and isolation of airborne influenza A H3N2 virus using a Sioutas Personal Cascade Impactor Sampler. Influenza Res Treat. 2013;2013:656825.

17. Webster RG, Yakhno M, Hinshaw VS, Bean WJ, Murti KG. Intestinal influenza: replication and characterization of influenza viruses in ducks. Virology. 1978;84(2):268-278.

18. WHO. Review of Latest Available Evidence on Potential Transmission of Avian Influenza (H5N1) Through Water and Sewage and Ways to Reduce the Risks to Human Health. Geneva: Switzerland; 2007.

19. Alford RH, Kasel JA, Gerone PJ, Knight V. Human influenza resulting from aerosol inhalation. Proc Soc Exp Biol Med. 1966;122(3): 800-804.

20. Tellier R. Review of aerosol transmission of influenza A virus. Emerg Infect Dis. 2006;12(11):1657-1662. 
21. Teunis PF, Brienen N, Kretzschmar ME. High infectivity and pathogenicity of influenza A virus via aerosol and droplet transmission. Epidemics. 2010;2(4):215-222.

22. Belser JA, Gustin KM, Katz JM, Maines TR, Tumpey TM. Influenza virus infectivity and virulence following ocular-only aerosol inoculation of ferrets. J Virol. 2014;88(17):9647-9654.

23. Verreault D, Moineau S, Duchaine C. Methods for sampling of airborne viruses. Microbiol Molec Biol Rev. 2008;72(3):413-444.

24. Fabian P, McDevitt JJ, Houseman EA, Milton DK. Airborne influenza virus detection with four aerosol samplers using molecular and infectivity assays: considerations for a new infectious virus aerosol sampler. Indoor Air. 2009;19(5):433-441.

25. Fabian P, McDevitt JJ, Lee WM, Houseman EA, Milton DK. An optimized method to detect influenza virus and human rhinovirus from exhaled breath and the airborne environment. J Environ Monit. 2009;11(2):314-317.

26. Sattar SA, Ijaz MK. Airborne viruses. In: Hurst CJ, Knudsen GR, Mcinerney MJ, Stetzenbach LD, Walter MV, editors. Manual of Environmental Microbiology. Washington, DC: ASM Press; 2002:682-692.

27. Oh S, Anwar D, Theodore A, Lee JH, Wu CY, Wander J. Development and evaluation of a novel bioaerosol amplification unit (BAU) for improved viral aerosol collection. J Aerosol Sci. 2010;41(9): 889-894.

28. Tseng CC, Li CS. Collection efficiencies of aerosol samplers for viruscontaining aerosols. J Aerosol Sci. 2005;36(5-6):593-607.

29. Reponen T, Willeke K, Ulevicius V, Grinshpun SA, Donnelly J. Techniques for dispersion of microorganisms into air. Aerosol Sci Technol. 1997;27(3):405-421.

30. Woo MH, Grippin A, Anwar D, Smith T, Wu CY, Wander JD. Effects of relative humidity and spraying medium on UV decontamination of filters loaded with viral aerosols. Appl Environ Microbiol. 2012;78(16): 5781-5787.

31. Woo MH, Hsu YM, Wu CY, Heimbuch B, Wander J. Method for contamination of filtering facepiece respirators by deposition of MS2 viral aerosols. J Aerosol Sci. 2010;41(10):944-952.

32. May KR. The Collison nebulizer: Description, performance and application. J Aerosol Sci. 1973;4(3):235-238, IN1, 239-243.

33. Ulevicius V, Willeke K, Grinshpun SA, Donnelly J, Lin X, Mainelis G. Aerosolization of particles from a bubbling liquid: Characteristics and generator development. Aerosol Sci Technol. 1997;26(2):175-190.

34. BGI. Collison Nebulizer - Instructions. Waltham, MA: BGI, Inc.; 2002.

35. Mainelis G, Berry D, An HR, et al. Design and performance of a single-pass bubbling bioaerosol generator. Atmos Environ. 2005;39(19): 3521-3533.

36. Gater ST, Peters KN, Kocsis AG, Dhariwala MO, Anderson DM, Anderson PE. Host stress and immune responses during aerosol challenge of Brown Norway rats with Yersinia pestis. Front Cell Infect Microbiol. 2012;2:147.

37. Stone BR, Heimbuch BK, Wu CY, Wander JD. Design, construction and validation of a nose-only inhalation exposure system to measure infectivity of filtered bioaerosols in mice. J Appl Microbiol. 2012;113(4): 757-766.

38. Peters TM, Leith D. Concentration measurement and counting efficiency of the aerodynamic particle sizer 3321. J Aerosol Sci. 2003;34(5): $627-634$.
39. Armendariz AJ, Leith D. Concentration measurement and counting efficiency for the aerodynamic particle sizer 3320. J Aerosol Sci. 2002;33(1):133-148.

40. TSI. Model 3321 Aerodynamic Particle Sizer ${ }^{\circledR}$ Spectrometer: Instruction Manual. Shoreview, MN: TSI Inc; 2001.

41. Asbach C, Kaminski H, Fissan H, et al. Comparison of four mobility particle sizers with different time resolution for stationary exposure measurements. J Nanopart Res. 2009;11(7):1593-1609.

42. Willeke K, Lin X, Grinshpun SA. Improved aerosol collection by combined impaction and centrifugal motion. Aerosol Sci Technol. 1998;28(5):439-456.

43. Lin X, Reponen T, Willeke K, Wang Z, Grinshpun SA, Trunov M. Survival of airborne microorganisms during swirling aerosol collection. Aerosol Sci Technol. 2000;32(3):184-196.

44. Hogan CJ Jr, Kettleson EM, Lee MH, Ramaswami B, Angenent LT, Biswas P. Sampling methodologies and dosage assessment techniques for submicrometre and ultrafine virus aerosol particles. J Appl Microb. 2005;99(6):1422-1434.

45. Riemenschneider L, Woo MH, Wu CY, et al. Characterization of reaerosolization from impingers in an effort to improve airborne virus sampling. J Appl Microbiol. 2010;108(1):315-324.

46. Farnsworth JE, Goyal SM, Kim SW, et al. Development of a method for bacteria and virus recovery from heating, ventilation, and air conditioning (HVAC) filters. J Environ Monit. 2006;8(10):1006-1013.

47. Cao G, Noti JD, Blachere FM, Lindsley WG, Beezhold DH. Development of an improved methodology to detect infectious airborne influenza virus using the NIOSH bioaerosol sampler. J Environ Monit. 2011;13(12):3321-3328.

48. Andersen AA. New sampler for the collection, sizing, and enumeration of viable airborne particles. J Bacteriol. 1958;76(5):471-484.

49. Thermo Fisher Scientific. Six Stage Viable Andersen Cascade Impactor [product specifications]. Franklin, MA: Thermo Fisher Scientific; 2010.

50. Lednicky JA, Wyatt DE. The art of animal cell culture for virus isolation. In: Ceccherini-Nelli L, Matteoli B, editors. Biomedical Tissue Culture. Rijeka: InTech; 2012:151-178. Available from: http://www.intechopen. $\mathrm{com} /$ books/biomedical-tissue-culture/the-art-of-animal-cell-culture-forvirus-isolation. Accessed October 30, 2014.

51. Hamilton SB, Wyatt DE, Wahlgren BT, et al. Higher titers of some $\mathrm{H} 5 \mathrm{~N} 1$ and recent human $\mathrm{H} 1 \mathrm{~N} 1$ and $\mathrm{H} 3 \mathrm{~N} 2$ influenza viruses in Mv1 Lu vs MDCK cells. Virol J. 2011;8:66.

52. Dukes JD, Whitley P, Chalmers AD. The MDCK variety pack: choosing the right strain. BMC Cell Biol. 2011;12:43.

53. Lugovtsev VY, Melnyk D, Weir JP. Heterogeneity of the MDCK cell line and its applicability for influenza virus research. PLoS One. 2013;8(9):e75014.

54. Guerin LF, Mitchell CA. A method for determining the concentration of air borne virus and sizing droplet nuclei containing the agent. Can J Comp Med Vet Sci. 1964;28(12):283-287.

55. Jensen MM. Inactivation of airborne viruses by ultraviolet irradiation. Appl Microbiol. 1964;12:418-420.

56. Spekreijse D, Bouma A, Koch G, Stegeman A. Quantification of dustborne transmission of highly pathogenic avian influenza virus between chickens. Influenza Other Respir Viruses. 2013;7(2):132-138.

57. Gustin KM, Belser JA, Wadford DA, et al. Influenza virus aerosol exposure and analytical system for ferrets. Proc Natl Acad Sci U S A. 2011;108(20),8432-8437.
Virus Adaptation and Treatment

\section{Publish your work in this journal}

Virus Adaptation and Treatment is an international, peer-reviewed open access journal focusing on the study of virology, viral adaptation and the development and use of antiviral drugs and vaccines to achieve improved outcomes in infection control and treatment. The journa welcomes original research, basic science, clinical \& epidemiological

\section{Dovepress}

studies, reviews \& evaluations, expert opinion and commentary, case reports and extended reports. The manuscript management system is completely online and includes a very quick and fair peer-review system, which is all easy to use. Visit http://www.dovepress.com/ testimonials.php to read real quotes from published authors. 